\author{
Снежана П. ВУЧКОВИЋ* \\ Филолошки факултет \\ Универзитета у Београду
}

\title{
О ОСНОВНИМ ТИПОВИМА ИСТОРИЈСКЕ ПРОМЕНЕ МОРФЕМСКЕ СТРУКТУРЕ РЕЧИ
}

\begin{abstract}
У раду се представљају основни типови историјске промене морфемске структуре речи, указује на узроке који их покрећу, механизме њиховог деловања и резултате датих промена на синхроном пресеку савременог српског језика. Упућује се на значај познавања датих промена не само за историјску већ и за синхрону морфемску или творбену анализу.
\end{abstract}

Кључне речи: историјске промене морфемске структуре речи, упрошћавање основе речи, перинтеграција, усложњавање, декорелација, аналогија, народна етимологија

1.1. У току историјског развитка језика не мења се само фонетски састав, парадигматска својства, лексичко значење речи него и њена морфемска структура. Промене у морфемској структури доводе до тога да се на неком синхроном језичком пресеку она у неким случајевима показује потпуно другачијом у односу на реконструисану прајезичку из које је произишла, или на ону потврђену на неким хронолошки ранијим синхроним пресецима.

Теоријске основе за даља промишљања о карактеру и природи, облику, значењу и функцији морфема, те њиховим променама у историјском развитку словенских језика дали су још представници Казањске лингвистичке школе (Де Куртене, Богородицки, Крушевски), дијахронијско-синхронијске по свом основном усмерењу. Они су писали о томе да облик, функција и значење морфема могу током времена варирати и да се као резултат тога јављају промене у морфемској структури речи - она може изгубити способност да буде морфемски дељива (упрошћавање морфемске структуре), границе међу морфемама могу се померати (перинтеграција), просте речи могу током времена проширити своју морфемску структуру (усложњавање) (Николајев 2007: 8). Касније су ове основне поставке биле прецизиране и допуњаване (нпр. у радовима настављача казањске лингвистичке традиције 
О. Винокура, В. Виноградова, Н. Шанског, Ј. Азарха), те се у руској лингвистичкој литератури среће и појам декорелације као једног вида морфемске прерасподеле који није праћен померањем граница међу морфемама (в. тачку 2.4). У историјској српској лингвистичкој литератури на поједине узроке преображаја морфемске структуре речи указивано је у оквиру праћења промена њихове парадигматске структуре или приликом констатовања историјских промена у творбеној структури речи (нпр. у радовима Белића, Бошковића, а затим и других аутора који су се бавили историјским аспектом развитка морфолошког и творбеног система српског језика). Самом питању типологије историјских морфемских промена није посвећивана посебна пажња ${ }^{1}$, како због тога што (творбена) морфемика није у нашој науци стекла статус засебне лингвистичке дисциплине, тако и због синхронијске усмерености наше савремене науке о творби речи као описне дериватологије која се користи дескриптивним методом.

1.2. Предмет овог рада је представљење основних типова историјске промене морфемске структуре речи, осветљавање узрока који их покрећу и њиховог често напоредног деловања, те констатовање резултата тих промена на нивоу савременог српског језика. Као почетну етапу тј. као исходишни морфемски модел у разматрању типова промене морфемске структуре узимамо онај који се у речницима псл. језика ${ }^{2}$ реконструише као примарни, док се резултати разматраних процеса прате на нивоу морфемског система савременог српског језика. Примери су бирани тако да илуструју дате промене и неке њихове аспекте. Приликом дефинисања неких од основних типова ових промена позивали смо се и на податке које о њима доносе терминолошки речници Симеона (ЕРЛН), Ахманове, велики руски енциклопедијски лингвистички речник (Лингвистический энцикопедический словарь (ЛЕС) $)^{3}$ ), као и неки други терминолошки приручници. ${ }^{4}$

2. Основни типови историјске промене морфемске структуре речи - $y n$ рошћавање, перинтеграција, усложњавањае и декорелација - као и још неки језички процеси који узрокују и прате ове промене попут аналогије и народне етимологије - манифестују своје резултате и на нивоу морфемског система савременог српског језика. На одабраним примерима представићемо механизам њиховог деловања и указати на неке њихове посебне аспекте.

\section{1. Упрошћавање основе речи}

Упрошћавање основе речи је историјски процес промене морфемске структуре при којем основа са првобитно полиморфемском структуром престаје да буде дељива на морфеме и претвара се у просту (морфемски недељи-

\footnotetext{
${ }^{1}$ На неке од овде разматраних морфемских промена позива се у свом тумачењу историјског развитка појединих творбених типова и Р. Маројевић (в. нпр. Маројевић 2014: 637-652).

2 ЭССЯ и СП.

${ }^{3}$ По броју одредница које садржи, карактеру и исцрпности дефиниција и посебно свом синхронијско-дијахронијском усмерењу овај терминолошки речник веома је репрезентативан не само за руску лингвистичку науку већ и за славистику уопште.

${ }^{4}$ В. библиографске референце у одељку Литература.
} 
ву) реч. ${ }^{5}$ Основни узроци упрошћавања, који такође ретко делују изоловано, могу бити:

a) фонетске промене: нпр. обрнути $<*$ *b-vrb-nQ-ti; caн $<*_{s ъ p-n ъ}$ (: *sъp-a-ti); пландовати < пладновати < *poldbnovati (,одмарати (се) око поднева"); једанаест (упор. стсл. юдннъ на АєсАтє); обед (: *ob-e d- : псл. *jasti, ,јести" < *ēe-ti), итд.;

б) морфонолошке и творбене промене: нпр. обарити (: *ob-variti; упрошћавање сугласничке групе $b v$ на морфемском шаву и перинтеграција префиксалног сугласничког елемента у састав творбене основе (упор. барити као депрефиксирану секундарну форму) $)^{6}$ ); топон. Трепча (српсл. $\operatorname{trqb} a) \Leftrightarrow * t e r b b c b$,онај који треби (крчи) шуму" $+-j b \Rightarrow$ terbbč $(v b s b)>* t e r b b c ̌ a$ (универбизација двочлане топонимске синтагме) $>$ Tрепча ${ }^{7}$;

в) прекид семантичких веза са сродним речима датог етимолошког гнезда тј. семантичка дивергенција деривата: нпр. недеља (: *neděl-a-ti); запад (:*za-pad-ti); ужина $(*(j) u g ъ)^{8}$, итд.

г) губљење или архаизација мотивне речи: нпр. сунще (: псл. основа *Sъln-, упор. стсл. вєскъньнъ ,таман, лишен сунчане светлости”, CC: 82); вест (: *véděti „знати”); оветшао / овештао (: *vetъhь „стари”, срп. арх. ветах), итд.

Ако током историјског развитка језика речи које имају просту основу нестану или буду архаизоване, тада се мотивациона веза са њиховим дериватима кида и временом ти деривати постају нове просте, морфемски недељиве немотивисане речи ${ }^{9}$ које могу постати и центром новог коренског гнезда (упор. нпр. ${ }^{*}$ pal» $^{10}$ : nалаu, *ula ${ }^{11}$ : улица, итд.).

${ }^{5}$ B. ЛЕС s. v. опрощение. Ахманова упрошћавање поистовећује са процесом деетимологизације: губљење етимолошке мотивисаности речи као последица кидања смисаоне везе са њеним етимолошким кореном и тесно спајање у једно цело при фузији морфема које улазе у састав изведених или сложених речи (Ахманова 1966: 130). Исто и у ЕРЛН (II: 213).

${ }^{6}$ Лома 2000: 603.

7 Лома 2013: 215-216.

8 Лексема ужина деетимологизована је због прекида асоцијативних веза које су је доводиле у везу са Сунцем односно са његовим положајем на небу у подне тј. у време узимања овог оброка (упор. подне „2. јужна страна неба, југ, јер на тој страни стоји сунце кад је подне (пола дана)”, PJA XX: 276, 278; стсл. помог дьнє „на југ, к југу”, СС: 202), као и због губљења протетичког гласа $j$ који се у њеној основи не јавља.

${ }^{9} \mathrm{O}$ односу мотивисаних и немотивисаних речи пише и проф. Б. Ћорић и наводи термине који се у литератури за ове друге срећу: просте речи, засебне, лексичке, праве, основне, усамљене, немотивисане (Ћорић 2008: 23).

${ }^{10}$ Упор. рус. беспа́льй, шестипа́льй (в. Фасмер III: 191-192).

11 „Прасловенска именица *ula првобитно је означавала 'шупљу стабљику, трску' односно 'шупљину стабљике или дебла'. Њен мушки парњак *ulъjb 'кошница' (заправо 'шупље стабло дрвета'), уобичајен је назив за кошницу у многим словенским језицима (бугарско улей, словеначко $u l j$, чешко $u l$, руско улей итд.). У српском та реч постоји само у дијалектима, нпр. у облику множине уљеви 'кошница' (забележио Вук Караџић у Срему), као и уљаник, улиште, такође у Српском рјечнику према Вуковим записима из југозападних крајева.” (Влајић-Поповић 2013: 105-107). 
Упрошћавање основе речи манифестује се и у појави тзв. везаних коренова у морфемској односно творбеној структури неке речи. Везане коренске морфеме су оне које се јављају само у споју са афиксалним творбеним морфемама (об-у-ти / из-у-ти, уз-е-ти / от-е-ти, при-вик-ну-ти / на-вик-ну-ти, $n m-u щ a / n m-u \hbar$ итд.) и не постоје самостално. ${ }^{12}$ У структури неке речи оне се могу издвојити ако постоји бар једна истокорена, генетски сродна реч у којој се везани корен јавља у споју са неким другим афиксом. ${ }^{13}$ Тако се, на пример, везани корен $n m$ - у лексеми $n m$-ица издваја путем поређења са истокореном речи $n m-u \hbar$ (у којој се јавља у вези са другачијим творбеним афиксом; упор. и укр. птах, птаха „птица”, рус. пташка „птичица”, птенец „птић”); корен -y- у лексеми об-y-ти на основу поређења са сродном лексемом из-y-ти, итд. Коренске морфеме у везаном облику по правилу губе своју семантичку прозирност јер се из језика изгубила лексема са којом би оваква, не до краја упрошћена морфемска односно творбена структура, стајала у јасној формалној и семантичкој вези. Говорећи о примерима сложених глагола (типа узети, отети, почети, начети) који су током историје изменили свој облик и који се на синхроном пресеку савременог српског језика не могу сматрати сложеним иако се префикс и даље формално може одвојити, Стевановић каже да је у њима „већ и свако посебно значење које би префикс собом носио сасвим ишчезло” (Стевановић 1991: 450). Слично утврђује и Б. Ћорић говорећи о немотивисаности придева разговетан: „У речи разговетан препознајемо сегмент раз- (срећемо га у изведеницама типа разбудити, разбацати и сл.) и сегмент - $a н$, који долази у бројним примерима типа страстан, гласан итд., а ипак се та реч не може посматрати као изведена, будући да средишњи део -говет- не упућује ни на какво значење које би било предано придеву разговетан." (Ћорић 2008: 25).

Везани коренови, историјски гледано, представљају једну од карика историјског ланца која повезује некада морфемски дељиве и нове просте, морфемски недељиве речи. На пример:

a) Данас се у лексеми унутра више не издваја њена бивша морфемски дељива структура: псл.*vъn-Qtrъ (упор. стсл. жтрь „унутра”, жтр-ова - 1. „утроба (тела)”; 2. „живот”; 3. „материнска утроба”; прен. „унутрашњост (чега); срце, душа”, хтр-ьнь „унутрашњи”, CC: 806). Дата лексема има у својој структури везан корен (упор. из-нутра) настао као резултат процеса перинтеграције: због померања морфемских граница између префиксалне и коренске морфе-

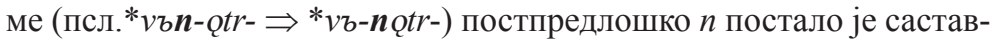
ни део корена и аналошки се уопштило. Морфемска дељивост дате речи могућа је само на основу поређења са семантички и морфемски блиским речима. Губљење датог историјског корена (*vъn-Qtrъ) у слободном, невезаном виду, промена његовог фонетског лика

${ }^{12}$ „Vezani korijen - korijen poznat samo u spoju sa primarnim afiksom” (Симеон 1969: II, 710).

${ }^{13}$ У синхронијској науци о творби речи оперише се појмом везаних (творбених) основа (упор. Клајн 2002: 212-244; Бабић 1986: 477-478) тј. оних које се јављају само у вези са неким творбеним афиксом и не постоје на синхроном пресеку неког језика самостално. 
( ${ }^{n}$ otr-), као и слабљење семантичких веза са другим речима истог гнезда (упор. данас већ донекле арх. лексему нутр-ина), воде упрошћавању основе дате речи, њеној десемантизацији и претварању у просту коренску лексему.

б) Везани корен срећемо и у групи глагола типа на-вићи / -викнути, с-вићи / -викнути, од-вићи /-викнути (несвр. -викавати) у чијој се морфемској структури историјски корен * $v y k$ - не може на синхроном нивоу реконструисати јер је током језичког развитка изгубљен као слободна коренска морфема (упор. упор. стсл. въл-нж-ти „привикнути, научити се, стицати навике, умење”, СС: 160). Иако њихов етимолошки корен *ouk- још постоји у дериватима из лексичко-семантичке групе глагола учити (наука, ученик и сл.), он се због низа историјских фонетских промена у споменутој групи глагола на савременом нивоу не препознаје и не доводи у везу са разматраним облицима. ${ }^{14}$ Свршене варијанте ових глагола (типа свићи, навићи, одвићи, привићи и сл.), такође су током историје мењале своју првобитну структуру (упор. нпр. ${ }^{*} s-v y k-t i>$ срп. свићu), те се и код њих основа глагола упростила и последично деетимологизовала. Упрошћавањем сугласничких група на морфемској граници и даљом деривацијом (упор. *ob-ฑyknQti $>$ *obyk-е̌jb > oбичaj) добијени су и потпуно деетимологизовани, морфемски недељиви деривати који на синхроном нивоу функционишу као просте лексеме.

Наведени примери показују да су историјске фонетске и морфемске промене и још више семантичка дивергенција у значењима неких деривата који припадају истом коренском гнезду довеле до кидања етимолошких веза те се границе везане коренске морфеме на синхроном нивоу постављају на основу представе о датом продуктивном морфемском моделу, као и на основу издвајања регуларних и продуктивних афиксалних морфема.

\section{2. Перинтеграичја}

О перинтеграцији као историјском процесу промене морфемске структуре речи који се односи на померање границе између морфема и који доводи до нове морфемске прерасподеле ${ }^{15}$, доста је писано у нашој литератури, на пример у вези са питањем формирања система флексијских наставака различитих врста речи у историјским граматикама, питањем порекла сложених по структури суфикса (упор. Бошковић 1978: 367, 4476, Стакић 2002: 81-88, Ћорић 1982: 225, 227), или у вези са променом морфемске односно творбене

${ }^{14}$ Етимолошки дифтоншки корен *ouk- био је током историјског развитка преобразован процесима монофтонгизације (упор. *uk-i-ti > учuтu, *na-ukiti $\Rightarrow$ научити, наука, научник), дуљењем коренског вокала ( $* \bar{u} k>*-y k$-) и усложњавањем коренске морфеме путем секундарне протезе $(* v-y k-)$ - упор. стсл. въкк-нж-тн - где се он јавља и у префигираном облику (упор. навъикнтт, навъгчнни, „познавање, поимање”, СС: 346$)$.

${ }^{15}$ ЛЕС, s.v. переразложение; Ахманова 1966: 319.

${ }^{16}$ Бошковић се служи и терминима (морфолошка) декомпозиција и престројавање морфема. 
структуре речи при којој део творбеног елемента (префикса или суфикса) прираста њеној основи (в. нпр. Лома 2000: 601-621). Перинтеграција је за процес промене првобитне морфемске структуре подједнако важна као и упрошћавање. Док је процесом упрошћавања српски језик током свог историјског развитка добио нове просте по структури речи, које су онда могле постати и центром новог коренског гнезда, процесом перинтеграције он се богатио и бројним новим творбеним афиксима и новим творбеним моделима.

Из великог броја примера издвојићемо само неке да овај процес илустpyjy:

a) перинтеграција у корист суфиксалне морфеме: нпр. у класи именичких девербативних деривата где се варијанте суфиксалних морфема јављају као последица перинтеграције основинског наставка датих глагола - упор. нпр. варијантне суфиксе *-telb / *-itelb где jе варијанта *-itelb добијена перинтеграцијом основинског наставка -i- у кругу датих глаголских основа (*goniti : *gonitelb, *děliti : *dělitelb, *pobéditi : *pobéditelb итд.) ${ }^{17}$, а затим се уопштила (упор. срп мрзети : мрзитељ, држати : (све)држитељ итд.); или варијантне суфиксе *-(e)nьje /*-tьje добијене перинтеграцијом наставака старих трпних партиципа који су се потом уопштавали и као самостални творбени елементи додавали и на основе непрелазних глагола (упор. *hoditi : *hoždenije, *bloditi : *blqždenije, *žiti : žitije, $*_{\text {sъniti }}{ }^{*}$ sъnitije, итд. $)^{18}$. Данас су суфикси -ње и -ће најпродуктивнији наставци за класу глаголских именица и додају се на различите типове глаголских основа. ${ }^{19}$

б) перинтеграција у корист основе: сумь- $a\left(\right.$ : сумњати) $\Leftrightarrow{ }^{*} s Q-m b n-j a$ (: *-mьn-е̌-ti); *vъn ědra (ак. мн. од *е́dro, „унутрашњост”; упор. грч. etor „срце”, etron „црево”) > *vъ nе́dra (упор. стсл. гадра „недра, груди, пазуси"; срп. ијек. њедра; рус. недра „дубине земље”); *kъn jeтu $>$ kъ n'eти (појава тзв. постпредлошког $n^{\prime}$ у облицима заменице трећег лица); арх. ку̀зница, „ковачница” (РСА 10: 770) - од псл. *kovati, *kujq $\Rightarrow$ псл. *ku-znь / *kb-znь „ков, оно што је сковано, ковани предмети” (упор. *žiznь : žiti, *bojaznь, *bolěznь и др.) $\Rightarrow$ *kuzn-bnica $\Rightarrow$ ку̀зн-ица „место где они настају; ковачница”, итд.

в) перинтеграција у корист падежног наставка: псл. наставак лок. једн. именица *-ॅ- основа мушког рода *oi $(>*$ *е̌) резулат је споја основинског и старог локативног падежног наставка; облик акузатива једн. именица *-ä- основа женског рода настао је такође као резултат перинтеграције основинског наставка (*ām $>Q>u)$; у срп. јез. наставак дат., инстр. и лок. множине именица ж. рода -ама (тип женама) настаје као резултат перинтеграције старог основинског наставка у састав дате флексијске морфеме, итд.

${ }^{17}$ Јефимова 2006: 65.

${ }^{18}$ Јефимова 2006: 134, 138

${ }^{19} \mathrm{O}$ природи и функционисању ових суфикса на савременом нивоу руског и српског језика в. Терзић 1969: 27-39. 
Узроци који доводе до процеса перинтеграције су различити. Могу бити везани за појаву закона отвореног слога у прасловенском периоду (тако се, на пример, може објаснити појава постпредлошког $n$ ' (некад у саставу предлога *vъn, *kъn, *sъn) у облицима заменице трећег лица, као и облици *od-rěšiti

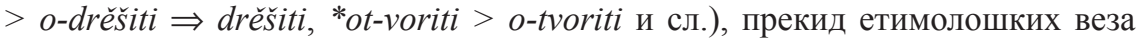
са речју која стоји у основи датог коренског гнезда (упор. нпр. *bъděti $\Rightarrow$ *bbd-rb $\Rightarrow$ *bbd-r-ostz : бoдp-ocm), непродуктивност некадашњих творбених модела, односно њихових творбених елемената (в. кузн-ица), спречавање стварања тешких за изговор сугласничких група на морфемском шаву корен на сугласник + суфикс који почиње сугласником (нпр. код суф. варијаната *-telb / *-itelb), гласовних промена које су довеле до разградње старог (индоевропског) система именичких основа на прасловенском нивоу (основински наставци почели су се схватати као део падежног наставка) итд.

\section{3. Усложнавање морфемске структуре речи}

Усложнавање је процес промене морфемске структуре речи при којој реч која се раније није могла делити на морфеме постаје морфемски дељива (Шански 1959: 129). Појава се пре свега односи на велики број позајмљеница које у језик прималац улазе као целе, морфемски недељиве лексеме и у његовом морфемском односно творбеном систему функционишу као просте речи (чак и онда кад су по свом пореклу морфемски дељиве). О даљој промени њихове морфемске структуре пише Б. Ћорић: „Међутим, ствари се у овом погледу током времена могу знатно изменити, па чак довести и до тога да споменуте лексичке јединице на новом терену покажу већи или мањи степен структурне рашчлањивости, што се може протумачити као последица укључивања ових формација у творбени систем језика примаоца." (Ћорић 2008: 69-70). У чланку Принципи творбене анализе стране лексике исти аутор наводи да се временом из неких од ових лексема може издвојити и суфикс који „формантску улогу добија на домаћем терену укључивањем у домаћи творбени систем"20, те набраја и услове који се у литератури обично издвајају као неопходни да би нека страна по пореклу лексема била морфемски рашчлањива: „а) ако се у језику примаоцу употребљава њихова творбена основа; б) ако се одређени суфикс може срести и у домаћим неологизмима; в) ако се модел (структура) позајмљеница поклапа са моделом (структуром) неких домаћих речи" (Ћорић 2008: 41-42).

Морфемска структура исконских, словенских по пореклу речи такође је могла током историје бити усложњена додавањем продуктивних (за дато значење) творбених суфикса на просту, на датом синхроном пресеку, основу. Овај вид усложњавања морфемске структуре потврђен је још на стсл. нивоу где су се, на пример, најпродуктивнији стсл. именички суфикси јављали у функцији актуелизације (обнављања) лексема које се на старословенском ни-

\footnotetext{
${ }^{20}$ Такви су нпр. турски по пореклу суфикси -ција, -лук, -лија, -ана итд. или интернационални суфикси -ист(a), -ат, -ор, -ант, -ура, -ада и њихове варијанте (Ћорић 2008: 40-51).
} 
воу препознају као просте, немотивисане речи. ${ }^{21}$ Разлог овој појави може се тражити у општој језичкој тежњи ка већој формалној изражајности узрокованој деетимологизацијом простих стсл. лексема. У функцији суфикса „проширивача” налазили су нпр.: а) суфикс-ьnikъ: схпьръ/сжпрьннкъ „супарник, противник”; б) -tel'b: съпасъ „спаситељ” (у јеванђељским текстовима много фреквентнија од варијантне суфиксиране лексеме) / съпаснтєкь; в) - всь:

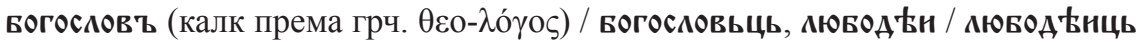
„прељубник”; г) -ьnica: кошь / кошьннца, сиокъ / сиокъвьннца; д) -ьје: огтро /

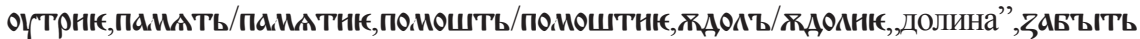
/ zавъттнє „заборав”, итд. (СС). Ови секундарно додати афикси не мењају значење творбене основе нити га модификују у извесном правцу, већ само маркирају припадност дате лексеме одређеној творбено-семантичкој категорији или лексичко-граматичкој класи: упор. нпр. срп. арх. тврђа (РСЈ 1306) : тврђава, лис (РСA 11: 470): лисаи, крњ : крњав, сињ : сињав, ћос : ћосав (Стевановић 1991: 550), тмур (РСЈ: 1322) : тмуран, итд.

Посебан тип усложњавања морфемске структуре представља секундарна афиксација која утиче на увећање броја творбених морфема у речи и при којој као резултат контаминације $\mathrm{e}^{22}$ функционално и семантички блиских творбених морфема могу настати нови сложени суфикси. Тако је, на пример, најпродуктивнији редупликациони модел у стсл. језику (у класи именица) био је онај који се односи на удвајање афикса са истим творбеним значењем. Афикси другог деривационог корака не мењају творбено или граматичко значење првог афикса већ га у потпуности понављају. На пример:

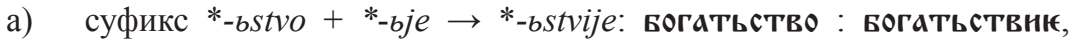
ГОсПОАЬСТВО : ГОСПОАЬСТВНК, ВАААЫЧЬСТВО : ВАААЫЧЬСТВНК, АнХонмьство : АнХОнмьствнє, Ажкавьство : Ажкавьствнє, отьчьство : отьчьствиє итд. (СС). Наведене творбене варијанте су апсолутно синонимичне, узајамно заменљиве у истом контексту, без стилистиличке, нити битне разлике у учесталости употребе. Прасловенски суфикс *-ьје био је најпродуктивнији старословенски именички суфикс, посебно у творби nomina actionis. Његово ширење изван сфере примарне употребе и на довољно продуктиван и изразит (регуларан) тип творбе изведеница са суфиксом -bstvo, може бити знак извесног преводилачког манира, наглашавања књишког карактера ових старословенских лексема, појаве коју Радосав Бошковић назива „суфиксални узус епохе” (Бошковић 1978: 364). У српском језику лексеме са сложеним суфиксом -ствије имају архаичан, књишки карактер и стилски су обележене (упор. путешествије, молепстивије), а творбени тип којем припадају изгубио је продуктивност.

${ }^{21}$ В. Јефимова 2006: 18-21.

${ }^{22}$ Термин контаминација односи се на комбиновање делова посебних суфикса који су обично у одређеном творбеном систему и функционално идентични (синонимни) (в. Ћорић 1982: $225,227)$ 
б) суфикс *-ostb $+*_{-y n} i \rightarrow *^{*}$-ostyn 'i: вмагость : влагостъын̂н „доброта,

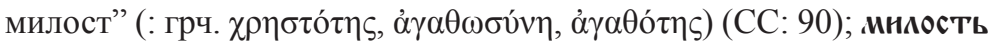
: мниост"Ыиिн 1. „милост, милосрђе”; 2. „милосрдни поступак, ми-

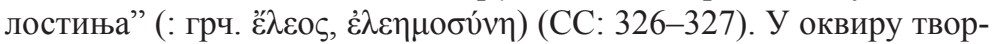
бено-семантичке категорије adjektivabstrakta прасловенски суфикс *-ostb био је у стсл. језику најпродуктивнији, са много више потврда од њему синонимичног суфикса *-yn'i који се јавља у само не-

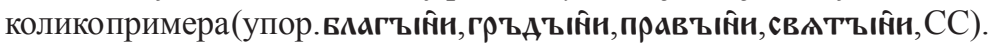
Напоредна употреба довела је до контаминације ових суфикса. Секундарно додавање мање продуктивног суфикса на основу примарно изведену продуктивнијим, синонимичним суфиксом, могло би стајати у функцији експресивизације тј. појачавања, наглашавања и истицања већ изражених творбених значења. Исти сложени суфикс у српском језику налазимо у називу манастира Љубостиња чија је основа већ упрошћена, са елементима који се могу само етимолошки издвојити или у лексеми милостиња која има резултативно значење и у којој је дошло до замене старе флексијске морфеме према данас продуктивном парадигматском типу. Аналогну формацију препознајемо у творбеном типу са апстрактним именичким суфиксом -ota у првом делу сложеног суфикса: босотиња, голотињ, сухотињ $а$ и сл. У значењу ових деривата постоји извесна негативна експресивна конотација.

\section{4. Декорелащија}

Декорелација је историјски процес промене морфемске структуре речи који се тиче измене карактера и значења морфема и њихових односа у речи. При овом процесу се не мења број морфема нити границе међу њима, већ се дешава њихова функционална и значењска прерасподела (Шански 1959: 130).

Издвојићемо неколико примера овакве врсте морфемске промене:

a) реанализа морфемске структуре именица прасловенских -s- (упор. стсл. ном. једн. чог/АО, ген. једн. чог(А-єс-є, ном. мн. чог(А-єс-а) или

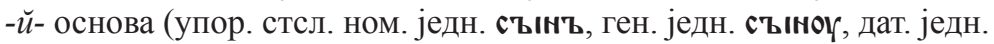
съмови) - при којој се стари основински наставак, који се сретао у зависним падежима (и једнине и множине) или само у неким па-

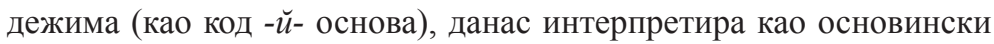
наставак за множину (чудо : чуда/чудеса, син : синови и сл.);

б) флексијски наставак - $а$ у номинативу једн. именица женског рода (типа жена) по пореклу је основински наставак старих *-̄̄- основа које у ном. једн. падежни наставак нису имале (Бошковић 2007: $126)^{23}$;

\footnotetext{
${ }^{23}$ По новијим тумачењима псл. *-ā- основе по пореклу су основе на ларингал $\left(*-\bar{a}-=\mathrm{eH}_{2}\right)$, али су већ у индоевропском прајезику имале моцијску функцију (према именицама -о̆- основа
} 
в) пошто је у старијем (бесфлексијском) типу индоевропских сложеница ${ }^{24}$ била садржана веома плодотворна могућност да се само непроменљивим обликом основе изразе различити падежни односи, то су управо ове сложенице постале аналошки узорак основном типу сложеница у прасловенском језику - оном са спојним вокалом -о-. Како је тип именичких основа са основинским наставком -б- био врло продуктиван у именичком морфолошком систему, то се овај тематски вокал декорелацијом тј. променом своје функције (од обличке постао је творбена морфема) и значења аналошки уопштио и код оних сложеница које су у функцији прве компоненте имале именицу са другачијим типом основинског наставка (упор. стсл. водонось, мювод 中н, мювод заи и сл.);

г) непродуктивни суфикс -ав који срећемо у лексеми љуббав (: љубити) такође је резултат процеса декорелације - основински наставак -ъv- који се

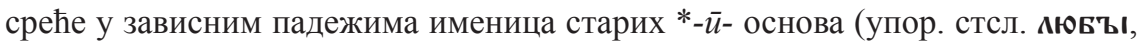
АюБъвє, АюБъвь, рус. любов), по новој језичкој интерпретацији добија статус творбеног афикса, итд.

\section{5. Аналошке промене морфемске структуре речи}

Појам аналогије, као једног од универзалних покретача развитка и функционисања језика, био је разматран још у учењима античких граматичара (аналогисти и аномалисти), младограматичара (у оквиру тезе о безизузетности фонетских закона - изузеци су тумачени управо дејством аналогије или позајмљеница) $)^{25}$, структуралиста (Сосирово разматрање аналогије као стваралачког принципа језика ${ }^{26}$ итд. Схваћена као процес формалног уједначавања унутар морфолошке парадигме једне речи (тзв. аналошко уједначавање) или као процес генерисања и проширивања морфолошког обрасца са једне лексичке јединице на другу, односно као пренос односа који постоје у једном пару језичких јединица на други пар језичких јединица (тзв. четворочлана аналогија) (в. Суботић 2002: 40-41) - аналогија је значајна и за објашњавање процеса промене морфемске структуре речи.

м.р.) или је дати наставак служио за творбу девербатива типа *paguba, *běda, *utěha (Михаљевић 2014: 46).

${ }^{24}$ Бесфлексијску епоху репрезентују сложенице у којима је именичка реч у непроменљивом облику основе испред управне речи могла значити различите падежне односе. У флексијској епоси облик самосталне именичке речи или било који други њен облик заменио је стару основу, те су се у сложеницама почели огледати различити падежи (Белић $1998: 137,174)$.

${ }^{25}$ Паул 1960: 128-142.

${ }^{26}$ Сосир 1989: 193-206. Полазећи од тога да ,аналогија сама за себе не може бити чинилац развоја”, Сосир утврђује да је „стална замена старих облика новим један од најупадљивијих видова трансформације језика. Сваки пут кад се једна креација коначно одомаћи и избаци свог супарника, имамо збиља нешто ново створено и нешто напуштено, и у том смислу аналогија заузима главно место у теорији развоја." (Сосир 1989: 202). 
Аналогија је двојствена по својој природи јер генерализујући неко правило или образац и увећавајући број регуларних, правилних форми она постаје носилац начела конзервације и системности у језику, а са друге стране, она је и носилац иновативног начела јер је узрок појаве нових облика у језику, затим неправилних, дублетних форми, изузетака и сл. Аналошка промена морфемске структуре речи може довести до тога да се речи - чији се етимолошки корен на савременом синхроном пресеку јавља само у везаном облику - морфемски сегментују погрешно, према обрасцу продуктивнијих речи или облика. Синхрона морфемска анализа, на пример, глаголе као што су отворити, затворити, притворити, растворити морфемски може сегментовати тако што издваја префиксалне морфеме (om-, за-, при-, раз-), слободну коренску морфему -твор- (: творити), обличку морфему -и- и инфинитивни наставак -ти. Дијахроно гледано, њихова примарна морфемска дељивост (*ot-vor $\left.{ }^{27}-i-t i\right)$ потрвена је због губљења мотивног глагола и нове, аналошке морфемске реинтерпретације која сугласнички елеменат префикса тумачи као део творбене основе (*o-tvor-i-ti).

Ми на овом месту аналогију наводимо као један од важних узрока промене морфемске структуре речи и не можемо примерима представити огромну масу случајева на којима се огледа дејство аналогијских феномена. Навешћемо ради илустрације само неке случајеве који се поглавито односе на аналошки мотивисане промене фонетског обличја морфема које чине основу речи или аналошке случајеве промене примарних флексијских морфема:

a) аналошка једначења унутар једне морфолошке парадигме (између основа једне речи): камен (упор. стсл. камъ, камєнє, камєнн, ка.мєь); дат., лок. једн. мени (упр. стсл. мьн') према ген. мене (упор. стсл. мєнє); дијал. ак. мн. орасе према ном. мн. ораси; 3. л. мн. хоће (упор. стсл. хотатъ) према хоћу, хоћеш итд.; инф. донети уместо *донести (упор. стсл. нєстн, нєсж) према аористу донех; 1. л. једн. аориста дадох (поред даx) према презенту (упор. арх. дадем, даду; стсл. 3. л. мн. презента АадАтт); импер. реци (упор. стсл. рьци) према през. речем, инф. рећи (стсл. рєщі, рєчєтъ); јес-

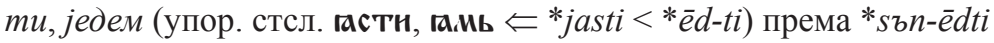
(стсл. сън'сттн) итд.

б) аналошка једначења између облика различитих речи: ген. једн. сина, камена (Упор. стсл. сънно, камєне) према града, оца (стсл. града, отьца); ном. / ген. једнине тело, тела (упор. стсл. тьло, т中иєсє) према село, села; дијал. сво уместо све према то; аор. запех (од запети), донех (од донети) према чух, пux, даx, знах и сл. (било је и *-pęsъ / *-pęhъ односно *nе̌sъ у облицима старог сигматског аориста); девет (стсл. Аєвлтъ уместо *nevę-, упор. стинд. náva, лат. novem, ствнем. niun) према десет (стсл. АєсАт' упор. лат. decem, лит. dēšimt); прилог дағу према ноћу (облик

\footnotetext{
${ }^{27}$ Псл. *vert-/*vort- „затварати” од ие. *иеr- „затварати, покривати” (упор. и врата, струс. воръ „ограда”, итд.) (Фасмер I: 350, 354-355).
} 
добијен процесом адвербијализације, од облика инстр. једн. нощтнюж); итд. ${ }^{28}$

\section{6. Народна етимологија}

Под народном етимологијом се обично подразумева погрешна представа говорних субјеката о мотивационим или етимолошким везама двеју речи заснована на њиховој фонетској или семантичкој блискости. ${ }^{29}$ Може бити узрокована непознавањем праве мотивације дате речи (веома често је то случај са позајмљеницама - каљача : нем. Kalosche ${ }^{30}$; топон. Липљан : лат. Ulpiana ${ }^{31}$ ), као и губљењем или архаизацијом мотивне речи (упор. топон. Купиново : псл. *kъlpъ „лабуд”, срп. дијал. кyn, пољ. kietp ${ }^{32} ;$ Гвоздаи : псл. * gvozdz ,густа шума, честар"33, и др.). Ову појаву може изазвати и аналошко преосмишљавање мотивационих односа по моделима неких сазвучних речи (упор. нпр. дијал. нераст „неуштројен мужјак животиње” (од псл. *nerst „парење (животиња)”) : *не-расти) ${ }^{34}$. Због аналошког преосмишљавања на основу принципа народне етимологије може доћи и до појаве ремотивације која одговора актуалном схватању односа и веза међу речима, односно до реанализе и преосмишљавања исходног модела морфемске структуре лексеме: нпр. каљ-ача: каљав (суфикс се додаје на редуковану придевску основу).

3. Познавање историјских процеса који воде измени морфемске структуре речи, узрока који их покрећу, механизма њиховог често укрштеног деловања, значајно је не само за историјски оријентисане радове из области морфологије и историјског развитка творбеног система српског језика него и за синхрону морфемску и творбену анализу. Оне у своје поље проучавања укључују разматрање природе и карактера, састава и односа морфема у структури једне речи, затим њихове семантике и продуктивности, веза и односа односа које имају са другим речима у систему савременог српског језика - али се у бројним случајевима показује да је потребно напустити раван дескрипције, прекорачити границе синхроног језичког система и ући у разматрање историје формирања одређене морфемске структуре да би поједини облици из класе изузетака, недовољно јасних, непродуктивних и нерегуларних, уникалних и варијантних форми и сл. били појашњени. У закључку желимо нагласити и да је за правилну синхрону творбену анализу неопходно јасно представити особености и мотивне и мотивисане речи као структурне

\footnotetext{
${ }^{28} \mathrm{C}$. Ившић, од кога смо преузели већину наведених примера, аналошка уједначавања дели на граматичка и појмовна. Прва се односе на а) једначења, од кога смо и преузели већину наведених примера, између основа једне речи (унутрашња) и б) једначења између граматичких облика различитих речи (спољашњ $а)$, док друга подразумевају једначења између речи којима се означавају сродни или супротни појмови (Ившић 1970: 24-30). О процесу аналогије и њеним подврстама, аналошким законима и тенденцијама в. Суботић 2002: 40-49, 95-105.

${ }^{29}$ Варбот и Журављев 2016, s. v. народна етиологија.

${ }^{30}$ В. Клајн 2003: 66.

31 Лома 2001: 13.

32 Лома, ibid.

33 Лома 2001: 15.

${ }^{34}$ В. ЭССЯ 25: 7-11.
} 
целине, са одређеним структурно-семантичким особеностима коренских и афиксалних морфема које је чине, те да је пре творбене анализе неопходно извршити и морфемску анализу језичких јединица које повезује одређени однос мотивације. Познавање процеса историјског развитка одређене морфемске структуре, често се показује, није у том поступку споредан и непотребан екскурс већ важан и комплементаран истраживачки поступак.

\section{ЛИТЕРАТУРА}

Ахманова 1966: О. С. Ахманова, Словар лингвистических терминов, Москва: Издательство „Советская энциклопедия”.

Бабић 1986: Stjepan Babić, Tvorba riječi u hrvatskom književnom jeziku, Zagreb.

Белић 1998: Александар Белић, Општа лингвистика (О језичкој природи и језичком развитку), Изабрана дела Александра Белића, том I, Београд: Завод за уџбенике и наставна средства.

Бошковић 1978: Радосав Бошковић, Одабрани чланции и расправе, Титоград: Црногорска академија наука и умјетности.

Бошковић 2007: Радосав Бошковић, Основи упоредне граматике словенских језика: фонетика, морфологија, грађење речи, Београд: Чигоја штампа.

Варбот и Журављев 2016: Ж. Варбот, А. Журављев, Краткий понятийнотерминологический справочник по этимологии и исторической лексикологии <http://etymolog.ruslang.ru/doc/etymology_terms.pdf. 3. 3. 2016>.

Влајић Поповић 2013: Јасна Влајић Поповић, Речите речи, Београд: Завод за уџбенике.

ЕРЛН - Симеон 1969: Rikard Simeon, Enciklopedijski rječnik lingvističkih naziva I-II, Zagreb: Matica hrvatska.

Ившић 1970: Stjepan Ivšić, Slavenska poredbena gramatika, Zagreb: Školska knjiga.

Јефимова 2006: В. С. Ефимова, Старославянская словообразовательная морфемика, Москва: Институт славяноведения РАН.

Клајн 2002: Иван Клајн, Творба речи у савременом српском језику, део први: Композищија и префиксащија; Београд: Завод за уџбенике и наставна средства, Нови Сад: Матица српска.

Клајн 2003: Иван Клајн, Творба речи у савременом српском језику, део други: Суфиксација и конверзија, Београд: Завод за уџбенике и наставна средства, Нови Сад: Матица српска.

ЛЕС: Лингвистический эничккопедический словарь <http://tapemark.narod.ru/ les/238a.html; 30. 6. 2019.>

Лома 2000: Александар Лома, Перинтеграција оБ- > 5 - као етимолошки проблем, Јужнословенски филолог, LVI/1-2, 601-623.

Лома 2001: Александар Лома, „Топономастика као изазов”, Книжевност и језик, XLVIII/1-2, 9-20. 
Лома 2013: Александар Лома, Топонимија Бањске хрисовуље, Београд: CAHY <http://aleksandarloma.com/PDF/Knjiga/A.Loma_Toponimija\%20B anjske\%20hrisovulje.pdf; 30. 6. 2019.>

Маројевић 2014: Радмило Маројевић, „Српски и словенски нулти суфикс”, у: Творба речи и юени ресурси у словенским језищима (Зборник радова ca 14. међунардоне научне конференције Комисије за творбу речи при Међународном комитету слависта), Београд: Филолошки факултет, 637-652.

Михаљевић 2014: M. Mihaljević, Slavenska poredbena gramatika, 2. dio, Zagreb: Školska knjiga.

Николајев 2007: Г. А. Николаев, Теоретические проблемы русского словообразования. Казанская научная школа, Диалектное словообразование, морфемика и морфонология, СПб: Наука, 7-29.

Паул 1960: Г. Пауль, Принциипи истории языка, Москва: Издательство иностранной литературы.

PJA3У: Rječnik hrvatskoga ili srpskoga jezika, Zagreb: Jugoslavenska akademija znanosti i umjetnosti, 1880/1882 - 1975/1976.

РСАНУ: Речник српскохрватског књижевног и народног језика, Београд : Српска академија наука и уметности, 1959-.

PCJ: Речник српскога језика, Нови Сад: Матица српска.

Сосир 1989: Ferdinand de Sosir, Opšta lingvistika, Beograd: Nolit.

СП - Słownik prasłowiański [ред. F. Sławski], том I-V, Polska akademia nauk, 1974-.

CC - Старославянский словарь, по рукописям X-XI веков, Москва: Русский язык, 1994.

Стакић 2002: Милан Стакић, Морфонологија и дериваџија: чланции и расправе, Београд: Филолошки факултет.

Стевановић 1991: Михаило Стевановић, Савремени српскохрватски језик I (Увод, фонетика, морфологија), Београд: Научна књига.

Суботић 2002: Ljiljana Subotić, Istorijska lingvistika, Novi Sad: Filozofski fakultet, Katedra za srpski jezik i lingvistiku.

Терзић 1969: Александар Терзић, „Структурно-семантичке одлике глаголских именица творбеног типа -ние, -ение, у руском и -ње, -ће у српскохрватском језику", Анали Филолошког факултета, IX, Београд, 27-93.

Ћорић 1982: Божо Ћорић, О структури суфикса у јужнословенским језицима, Книжевност и језик, XXVIII, 3-4, 225-230.

hорић 2008: Божо Ћорић, Творба именица у српском језику (одабране теме), Београд: Друштво за српски језик и књижевност Србије.

Фасмер 1986/1987: М. Фасмер, Этимологический словарь русского языка, I-IV, Москва: Прогресс.

Шански 1959: Н. М. Шанский, Очерки по русскому словообразованию и лексикологии, Москва.

ЭССЯ - Этимологический словарь славянских языков [ред. О. Н. Трубечев], том 1, Москва: Наука, 1974-. 


\section{Snežana P. Vučković \\ ON PRIMARY TYPES OF THE HISTORICAL CHANGE IN MORPHEMIC WORD STRUCTURE}

\section{Summary}

The primary types of the historical change in morphemic word structure - de-etymologization, metanalysis, expansion of stem, the change in the meaning of morphemes and their relations within a word without the change in the number of morphemes or their boundaries, as well as some processes causing or following these changes, such as analogy and popular etymology - manifest the change results at the level of contemporary Serbian language's morphemic system as well. Understanding of the historical processes leading to the change in morphemic word structure has also proven to be significant for synchronic morphemic and derivational analysis, especially when it comes to exceptions. The exceptions are non-productive and irregular forms based on which old productive morphological and derivational types can be reconstructed while the causes and pathways of their change during the language's historical development can be identified.

Key words: historical changes in morphemic word structure, de-etymologization, metanalysis, expansion, analogy, popular etymology 